384 Masenya, “Absent Husbands and Waiting Wives,” OTE 30/2 (2017): 384-402

\title{
Towards an MIT-Conscious Biblical Studies in South Africa? Glimpsing the Stories of Absent Husbands and Waiting Wives
}

\author{
Madipoane MASEnYa (NGWAN’A MPHAHLELE) (UNISA)
}

\begin{abstract}
When considering the place of Biblical Studies as a school subject in South African history, one cannot but be reminded of the (predictable) fate of the proverbial eagle. Says one African proverb: o se bone go akalala ga bonong, go wa fase ke ga bona (do not be puzzled by the (pride) of an eagle which soars so high, its fall is certain). Considering the present (slippery) place of (traditional) Biblical Studies as offered in South African institutions of higher learning, the subject's future appears to be gloomy. In the era of the MIT's (Multi-, Inter-,and Transdisciplinarities), biblical scholars should be persuaded to move away from their discipline-specific silos to engage with other disciplines in order for the subject to enrich other disciplines and vice versa. If disciplines such (African) History and Folklore Studies are made to interact with the subject of Biblical Studies, which contribution may such a "merger" bring to biblical scholarship in (South) Africa today? As an attempt to answer the preceding question, this article will use the stories of two waiting women, that is Dora Motshabi (cf. the South African context) and Bathsheba (cf. the monarchic Israelite context) as enablers for the construction of an MIT-conscious Biblical Studies.
\end{abstract}

KEYWORDS: biblical hermeneutics, Biblical Studies, proverbial eagle (nong), waiting women/wives, Bathsheba, and Dora Motshabi

\section{A INTRODUCTION}

It was in the early nineties, when the honouree, Professor Sakkie Spangenberg ${ }^{1}$ (then Dr. Spangenberg) presented a paper at one of the conferences of the then

* Article submitted: 28/02/2017; peer-reviewed: 9/05/2017; accepted: 23/05/2017. Madipoane Masenya (Ngwan’a Mphahlele), “Towards an MIT- Conscious Biblical Studies in South Africa? Glimpsing the Stories of Absent Husbands and Waiting Wives,” Old Testament Essays 30 (2017): 384-402, doi: http:// dx.doi.org/10.17159 /2312-3621/2017/v30n2a12

1 Professor I. J. J. Spangenberg has invested much of his teaching time at South African universities in the subject of Biblical Studies among others. He is thus aware of the "glorious" days of the subject as well as of the events which led to its downfall. It is thus fitting that an article which honours his scholarship, his commitment to offerings that would impact on the daily lives of the people, and in which a possible 
Biblical Studies Society of Southern Africa. ${ }^{2}$ The paper rose the concern of one of my former colleagues at the then University of the North (now University of Limpopo), the late Rev. Jacob Ramafuthula, concerned. Ramafuthula, like Spangenberg was attached to the Dutch Reformed Church (DRC) of South Africa. Informed by the atmosphere in the DRC of the time, Ramafuthula marvelled at Spangenberg's boldness and courage to present such a paper. "This young man is not afraid," Ramafuthula remarked. "How is he going to navigate the wrath of the church authorities?” In retrospect, I realise that Ramafuthula's fear was a confirmation of how the apartheid regime had unsettled the identities of South African black folks. Our priorities were simultaneously confused. Rather than appreciating the solidarity that a white colleague extended to black colleagues, I thought, my colleague was more concerned about Spangenberg's "safety" in the face of a possible onslaught from the DRC. Spangenberg seems to have been persuaded that a useful hermeneutic, one from the margins, was a necessity. To me it seems that already then the honouree was persuaded that OT/Biblical Studies could not have been researched and/or taught detached from the contexts of people on the grassroots, especially those on the margins. In this article which is meant to celebrate Prof. Spangenberg's context-conscious scholarship, I revisit the place of Biblical Studies, a subject that the honouree had actually invested much of his energies in for decades. Spangenberg retired being very much aware of the discipline's shaky position within the context of South Africa's Higher Education offerings. I would like to check the kind of product we may have, if the subject were to be theorised and practised in the context of the MIT's.

In an open-distance learning institution like the University of South Africa (UNISA), an institution to which the author and the honouree are attached, academics and all those who are involved in the construction of new offerings, are also being encouraged to revisit traditional definitions and constructions of discipline-specific academic offerings.

Within the context of a comprehensive open distance learning institution that UNISA is, ${ }^{3}$ academics are encouraged to embark on offerings that would cut

new way of offering Biblical Studies in our African contexts is examined, be dedicated to him.

2 See Izak (Sakkie) J. J. Spangenberg, "Paradigm Changes in the Bible Sciences and the Teaching of Biblical Studies in the New South Africa,” Scriptura 52 (1995): 1-10.

3 Barney N. Pityana, the then Principal and Vice-Chancellor of the University of South Africa argued as follows: “Unisa's broad agenda is echoed in the Institution's mission statement, namely to promote critical scholarship from an African perspective and to fulfil the mandate of a comprehensive university by providing academic offerings which range from general to vocationally oriented programmes. As part of this process Unisa established the Centre for African Renaissance Studies (CARS) in 2003, with the aim of promoting a Multi-Inter-and Transdisciplinary (MIT) approach to the knowledge by focussing on African Renaissance studies and pursuing cutting edge research through an interdisciplinary paradigm." Barney N. Pityana, "Open 
across disciplines through employing multi-, inter- and transdisciplinary approaches (cf. the MIT's). ${ }^{4}$ The discipline of Biblical Studies is housed in the School of Humanities within the College of Human Sciences (CHS) at UNISA. As part of its mission, the CHS seeks "to realize an Africanized provision of excellence ... in our research on multi-inter-and transdisciplinary engagement, reflexive practice and collaborative practice."5

Due to its commitment to foregrounding the MIT's core business, UNISA also established an Institute for Open and Distance Learning (IODL).

IODL is home to a rich variety of researchers from a range of disciplinary backgrounds. We embrace multi-, inter-and transdisciplinary approaches to researching ODL praxis whether as individuals or in interdisciplinary teams. ${ }^{6}$

The offering produced could reflect a combination of disciplines (cf. a multi-disciplinary offering) as will hopefully unfold during the course of this article. A discipline could also be made to go beyond itself to merge with other disciplines (trans-disciplinarity). It could also reveal that it is a product of a deliberate inter-disciplinary dialogue. Although the point of departure for an engagement with an MIT-conscious Biblical Studies will be the University of South Africa, given the present state of the subject (and religion subjects) in South African universities, as well as elsewhere on the African continent, it would not be an exaggeration to argue that the subject's survival (in Africa and beyond her borders) may be guaranteed if it were to adopt, among others, an MIT-conscious slant.

The MIT context, as it will become evident during the course of this article, enables the content of a subject such as Biblical Studies to impact the daily lives especially of those on the margins of our communities. As already noted, the main objective of this article is to propose that Biblical Studies be

Distance Learning in the Developing World: Trends, Progress and Challenges," Keynote address at the 23rd ICDE World Conference on Open Learning and Distance Education on Flexible Education for All, Open-Global-Innovative, 7-10 June 2009, Maastricht, the Netherlands, 14-15, http://uir.unisa.ac.za/bitstream/handle/10500 /411/ICDEMaastricht250609.pdf?sequence=1.

4 It seems to me that the Society of Biblical Literature endorses a similar practice in suggesting to would-be proposers of new seminars and sections to try and find a home within existing, albeit related/cognate sections.

5 “College of Human Sciences: About the College," UNISA, http://www.unisa.ac .za/sites/corporate/default/Colleges/Human-Sciences/About-the-college.

6 "Institute for Open and Distance Learning (IODL): Attending to Your Needs," UNISA, http://www.unisa.ac.za/sites/corporate/default/Colleges/Graduate-Studies /Schools,-Institutes-\&-Research-Chairs/School-of-Transdisciplinary-ResearchInstitutes-(STRI)/Institute-for-Open-and-Distance-Learning-(IODL)/Attending-toyour-needs. 
integrated with other disciplines in order for it to be contextually relevant, and thus useful. The disciplines of African Folklore and African (female) history will be integrated with the biblical material within the South African context. In order to give a glimpse of the state of the discipline of Biblical Studies in present day South Africa (cf. Section C here below), ${ }^{7}$ I will use a Northern Sotho proverb as a window. The proverb, o se bone go akalala ga bonong, go wa fase ke ga bona ${ }^{8}$ is translated literally as, "do not be puzzled by the sight of an eagle which soars so high, its fall is certain/it will soon fall down!” Its tenor reveals that pride goes before a fall. As an introduction, I will thus give a brief description of Northern Sotho proverbs within the context of African Folklore, also giving the readers a small glimpse of the IKS's (Indigenous Knowledge Systems). The African lore covers a wide range of elements such as proverbs, riddles, songs, idioms, and folktales among others. This article will only provide a very small window into the discipline of Northern Sotho, that is, Northern Sotho proverbs. It will be followed by an exploration of some aspects of African- South African female history. The latter history will feature the story of Dora Motshabi, one of the heroines who also made an important contribution to South African political history. Motshabi's story will hopefully enable one to unpack the main theme around which the construction of an MIT-conscious Biblical Studies offering proposed here rotates, that is, the trope of "(male) departures, (female) waiting and (male) returns.” The narrative of Motshabi will then be followed by my engagement with the following important question: if the preceding theme is applied to a HB female biblical character such as Bathsheba, which insights might emerge? Might such insights be helpful towards the construction of an MITconscious Biblical Studies in South Africa?

\section{B PROVERBS IN AFRICAN FOLKLORE}

The question on how the earliest African (Northern Sotho) proverbs ${ }^{9}$ were formed and by whom, is purely guesswork. Although it is not easy to trace their origins, it may be safe to conclude that the proverbs originated from

\footnotetext{
7 See also Madipoane Masenya, "Biblical Studies in South(ern) Africa: An Overview," in Handbook of Theological Education in Africa, ed. Isabel A. Phiri and Dietrick Werner (Pietermaritzburg: Cluster Publications, 2013), 454-465.

8 J.R.D. Rakoma, Marema-ka-Dika Tša Sesotho sa Lebowa (Pretoria: J.L. Van Schaik LTD, 1971), 201.

9 Authors writing on Northern Sotho usually distinguish between "idioms" and "proverbs" (dika le diema) and "sayings"/“aphorisms" (mebolelwana). Proverbs are built around nouns while sayings are based on predicates or infinitives. See Jacobus S. Bezuidenhout, "Die Noord-Sotho spreekwoord en -gesegde: 'n Stilistiese analise," (MA diss., University of Potchefstroom, 1981), 17; Samson M. Guma, The Form, Content and Technique of Traditional Literature in Southern Sotho (Pretoria: Van Schaik, 1977), 65; Stanley H. Brandes, "The Selection Process in Proverbs Use: A Spanish Example,” SFQ 38 (1974): 66.
} 
individuals or even groups of people. They were then later adopted by communities. There are different possible origins for these proverbs. Some of them are closely related to the idioms. Some proverbs originated from mythology, some came from folk-tales while others have their origins from history. ${ }^{10}$ Most of the proverbs, however, came as a result of careful observation by community members of human and animal behaviour and the observation of things in general in the environment. ${ }^{11}$

Proverbs constitute a wisdom genre of African folklore. They are the sum total of the community's everyday life experiences. ${ }^{12}$ Proverbs embody the qualitative and the corporate experience of the community in various situations, also displaying the wit and wisdom of the community whose heritage they form. ${ }^{13}$ James McLaren's could thus argue

There is little doubt that the shortest route to a knowledge of the Bantu psychology and the Bantu ethics is through the study of their proverbs on the one hand, and their folklore and fables on the other. ${ }^{14}$

African proverbs are characterized by fixity and rigidity of form to which they always adhere. ${ }^{15}$ They are situation-bound as a specific situation is restated in figurative terms while a comment is made on the situation. Hence, a proverb, more than all the other items of folklore, gives us a clear relationship between the item of folklore (cf. a proverb for example) and the indigenous social reality which it portrays. ${ }^{16}$

Proverbs form an integral part of life in varying African settings. They thus enjoy usage in various settings such as in the following:

Proverbs have a didactic function. They are therefore used to educate, inspire, warn and advise. ${ }^{17}$ Some proverbs are used in oratory while others

10 Cyril Nyembezi, Zulu Proverbs (Johannesburg: Witwatersrand University, 1954), 5.

11 Nyembezi, Zulu Proverbs, 6; Bezuidenhout, "Noord-Sotho," 21-66.

12 Alexander H. Krappe, The Science of Folklore (London: Methuen, 1965), 148.

13 Guma, The Form, 65; Pieter A. Duminy, African Pupils and Teaching Them (Pretoria: Van Schaik, 1968), 32.

14 James McLaren, "The Wit and Wisdom of the Bantu as Illustrated in their Proverbial Sayings,” SAJS 14 (1977): 332.

15 Guma, The Form, 65; Brandes, "Selection Process,” 172; R. A. Monyamane, "The Northern Sotho Proverb: A Survey of the Northern Sotho Proverb with Respect to its Definition, Characteristics, Classification, Form and its Functional Value/Significance,” (Honours article, University of South Africa, 1979), 2; Peter Seitel, Proverbs and the Structure of Metaphor among the Haya of Tanzania (Michigan: Ann Arbor, 1972), 5, 70.

16 Seitel, Proverbs, 5-6.

17 Bezuidenhout, "Noord-Sotho," 135; Nyembezi, Zulu Proverbs, xii. 
Masenya, “Absent Husbands and Waiting Wives,” OTE 30/2 (2017): 384-402 389

perform a juridical function. Proverbs can also assume an advisory function and they can be used euphemistically. They are also used to name the practicability of certain things. ${ }^{18}$

Proverbs have stylistic functions. It is no wonder that they can be used as titles for certain (literature) books. Proverbs can also be used to complete a discussion on a specific matter, thus serving as a summary of the content of a specific topic. ${ }^{19}$ Proverbs are used to throw some ambiguity into a discussion of a particular topic. This type of proverb usage is limited to particular circumstances. ${ }^{20}$ Proverbs can also serve to convince the listener that the opinion of the speaker is correct, ${ }^{21}$ and they can be used for entertainment.

The Northern Sotho proverb, o se bone go akalala ga bonong, go wa fase ke ga bona could be used stylistically as a heading to the topic under discussion (cf. its partial use here below). It could also be used towards the end of Section $C$ here below, to summarise the contents of the section. In the present article, the proverb is used didactically to educate, to inspire and to warn. What/who is the proverbial eagle in the context of the present discussion? To the preceding question we now turn.

\section{FACING THE FATE OF THE PROVERBIAL EAGLE? BIBLICAL STUDIES IN SOUTH AFRICA}

The history of the discipline of Biblical Studies in apartheid South Africa, may be summarised as follows: In apartheid South Africa, Christian National Education shaped all higher education offerings, including the discipline of Biblical Studies. Within the Bantu Education set-up, there was a compulsory school subject known as Religious Education. In actual fact it was Christian Religious Education which was universalised as Religious Education. At some point, a subject named Biblical Studies was introduced as one of the matric subjects in some of the black high schools. It became a very popular subject due to the straightforward way in which the subject matter of the main text book was cast, and the tendency for the examiners to repeat the same questions over the years. As a result, the students could "spot" the right questions and pass the subject in flying colours! The inclusion of Biblical Studies within the matric (highest school level) curriculum meant that interested or rather desperate students entering university for the first year, would also be able to register for the subject at university level.

18 Bezuidenhout, "Noord-Sotho," 143-144; Seitel, Proverbs, 245; Ruth Finnegan, Oral Literature in Africa (Oxford: Oxford University, 1970), 408-414.

19 Seitel, Proverbs, 255-257.

20 Seitel, Proverbs, 252-255.

21 Seitel, Proverbs, 248-249. 
On account of the popularity of the subject, in the eighties and nineties, thousands of first year university students, as Spangenberg can affirm, could register for Biblical Studies in both faculties of the Arts and Theology. As proverbial eagles, both the subject, whose content was mostly detached from the harsh realities of South African black life, and its teachers, were soaring high. The teachers, especially academics at universities, did not have to worry like many of us today, about future possibilities of retrenchments due to very low student numbers. The preceding "feast" though, would not last so long with the new dispensation. Not only did the new regime plan to make a clean slate with the past, especially given the role of the Christian religion in the oppression of Black people, but also Biblical Studies was removed from the curriculum as a school subject! As a result, students who were keen to pursue the subject at matric level, could no longer do so. Consequently, there was a significant drop in new registrants for this subject at university level.

One of the arguments behind the loss of popularity in the subject was that there was an over-production of secondary school teachers in the humanities. Many students, who then registered for the subject at university level, ended up not majoring in it. Consequently, very few ventured into graduate studies with Biblical Studies as a field of study. Does it come as a surprise, that even up to this day, very few black South African scholars remain with a PhD in Biblical (HB) Studies? The preceding observation is a major setback given the Eurocentric orientation of academic Biblical Studies syllabi and the mushrooming of many neo-Pentecostal and Charismatic pastors with little or no proper training in academic Biblical Studies and Theology.

The reduction in the number of Biblical Studies students, coupled with a call by the government for students to study subjects like maths, science and technology rather than the humanities, ended up not only in a severe reduction of students' enrolments in the humanities, but also in lower enrolments for academic Biblical Studies and Theology. The discipline of Theology lost its "sovereign" status as a faculty in universities such as the University of South Africa, the University of Limpopo and the University of Zululand among others. ${ }^{22}$ The fall of the proverbial eagle has been certain. Could there be a way out, especially in the way we currently teach Biblical Studies? Could immersing the discipline of Biblical Studies within the scope of the MIT's assist not only by keeping the discipline alive, but also, taking our cue from Prof. Spangenberg, by integrating it with the daily lives of grass root people?

22 Noteworthy is the fact that some of the universities still have their faculties of theology intact. Examples in the latter category are the University of Pretoria, the University of Stellenbosch and the University of the Free State among others. Also, within the category of the universities whose faculties of theology were shut down, theology offerings basically still remain albeit as part of the Humanities. 
Masenya, “Absent Husbands and Waiting Wives,” OTE 30/2 (2017): 384-402 391

As noted in the introduction, the trope of "(male) departures, (female) waiting and (male) returns" is used as a pivot around which the present investigation is made. The stories of Dora Motshabi and Bathsheba will be used to illustrate the theme. To the latter we now turn.

\section{DEPARTING (AND RETURNING) HUSBANDS AND WAITING/EXPECTANT WIVES}

In his novel titled, “The Cry of Winnie Mandela,” Njabulo Ndebele relates the narratives of fictitious women whose stories provide the readers with the life of African women especially during the time of the apartheid regime in South Africa. Their narratives are presented first, as though Winnie Mandela was an invisible, or a rather passive member of the audience. They are then followed by the response of a portrayal of the life of yet another important female figure in South Africa's apartheid history, Winnie Nomzamo Mandela. Elsewhere in the narrative of her response Winnie Mandela is purported to have argued, "Departures. Waitings. Returns. How right you are! Three pillars of a South African woman's life ..."23

From the narratives of these female figures, one cannot but note the important role which black women played in South Africa's history. They sustained families as they grappled with their husbands' departures. The women also engaged in the exercise of waiting. The exercise of waiting itself, was and still is taxing, as it still faces many an African woman today. Waiting indefinitely, especially if one is not sure about the return of the object of one's waiting can be devastating and debilitating. Some women waited for men who never returned (cf. Manete Lejona). Some waited, and even with their meagre salaries supported the education of their spouses who were in exile, only to be greeted by divorce papers ${ }^{24}$ upon their return (cf. Mamello and Winnie). Others waited only to come and be met by rejection from returning spouses as the women would have failed to stay with the proper, or rather pure seed (cf. Patience). ${ }^{25}$ Some waited only to be greeted by assaults, the latter, ironically in the name of love! Some women waited and of course enjoyed the desired happy reunions. Whatever the case was, these female children of the African soil, kept the fires burning by waiting patiently.

In the following paragraphs, I give a narrative of one of the South African women who not only experienced the pain and torture after her husband's

23 Njabulo Ndebele, The Cry of Winnie Mandela (Claremont: David Philip, 2008), 87.

24 Refer also to the life of Ruth Mompati, one of the political struggle heroines, whose married life ended in divorce due to political reasons among others. South African Democracy Trust, "Ruth Mompati," in The Road to Democracy: South Africans Telling their Stories, Volume 1, 1950-1970 ed. South African Democracy Education Trust (Hollywood: Tsehai Publishers and Distributors, 2008), 307-318.

25 Ndebele, Winnie Mandela, 9-84. 
departure, her waiting period and his return, but also suffered the harassment of the apartheid regime due to her active involvement in the struggle for the emancipation of black people in South Africa. The discipline of history, including that of the history of African peoples in South Africa not only basically features men as political heroes, it is mainly written by men. In an attempt to benefit from the discipline of (African) history, I have deliberately selected the narrative of Dora Motshabi because her story is seldom (if at all), heard by South Africa's (public) ear. Motshabi's story will give the readers a small glimpse of the lives of the majority of South African blacks during the period of apartheid here in South Africa. Her story, will also reveal to readers that Black South African women ${ }^{26}$ and not only men, were also involved in the struggle for the freedom of our people.

\section{E THE STORY OF DORA MOTSHABI}

Dora Motshabi hailed from Kubu in Polokwane, but born in Newclare, south of Johannesburg on 2 August 1928. Her primary education occurred at a Catholic school called St. Francis Xavier in Sophiatown. Due to the slum conditions in Newclare, life was not good at all according to Dora Motshabi. The population was a mixture of Blacks/Africans, Indians, Chinese and Coloureds. ${ }^{27}$ The family suffered a great deal as it relied on the very meagre earnings of a mom who was a domestic worker (two pounds and ten shillings per month). They all lived in the only one room which served as a kitchen, bedroom and sitting room at the same time. The police created another problem especially for women who were selling African brewed beer. After dropping out of nursing school, Motshabi went to work as a privately paid teacher at Bantu United School. When growing up, she was not involved in politics, her mother's Christian faith being the main hindrance. During that period, children were not supposed to go to the streets. However Dora Motshabi knew the names of Ntate JB Marks and Aubuti Sambie who crossed the country and died in Basutoland. They were ANC members who stayed in Newclare. ${ }^{28}$ She married a politically conscious Motshabi on 8 May 1958. Motshabi's family then lived at JZ Section in Moroka, a place called

26 See for example, the life of Albertina Sisulu as revealed in an interview by Miriam Tladi: Miriam Tladi, "Interview with Mrs Albertina Sisulu," in Sometimes When it Rains: Writings by South African Women, ed. Ann Oosthuizen (London: Pandora, 1987), 170-178; and also the story of Ruth Mompati, "Ruth Mompati." The Road to Democracy: South Africans Telling their Stories, Volume 1, 1950-1970. ed.

South African Democracy Education Trust (Hollywood: Tsehai Publishers and Distributors, 2008),307-318

27 South African Democracy Trust, "Dora Motshabi," ed. South African Democracy Education Trust, The Road to Democracy: South Africans Telling their Stories, Volume 1, 1950-1970, ed. by South African Democracy Education Trust (Hollywood: Tsehai Publishers and Distributors, 2008), 319-330.

28 South African Democracy Trust, “Dora Motshabi,” 320. 
Masakeng where people who came from different areas, settled in shacks. ${ }^{29}$ Before the couple went to live in Mapetla in 1957, they had a second child. It was during the time of the anti-pass campaign. Through her marriage, Dora Motshabi's political consciousness became entrenched. Motshabi was challenged by Winnie Mandela, MaSisulu and Lilian Ngoyi not to go to work as they reminded her that her husband was a leader. They marched to the police station in town and were arrested on arrival. Dora, thinking about her baby girl, also hoping that they would get bail in that same evening, was so disappointed because the other women insisted that they did not want to get bail! They all stayed in a cell called Number 4 for nine days. At some point, those in charge promised the women that they were going to sleep at a special place. Dora reports the horror of the place:

It was a horrible place; they were very big lice all around; they seem to have poured them there. You could not sleep for the whole night. The following day we said: "No, we are not going there again. You rather kill us." 30

After the arrest, Dora Motshabi joined the ANC Women’s League.

Meetings used to be held in Motshabi's house and one day the notorious police unit called the Special Branch arrived to search the house. Dora Motshabi's husband and his group managed to escape. Motshabi used to keep herself posted regarding when and where the activists were going to hold meetings. She could thus write; “Thus, I got politics when I got married.” As her husband, Motshabi, was actively involved during the anti-pass campaigns, being arrested (read: his constant absence) became his fate. Dora Motshabi's exercise in waiting for an absent husband started then. The climax occurred in 1965 when her husband crossed (skipped) the country. Motshabi did not inform his wife about his intentions except to leave a small goodbye note on a cigarette box. The Boers (to use Dora Motsabi's terminology) came in within a week or two, searching the house, demanding to know his whereabouts. They began to harass Dora for an expected answer that was not forthcoming. How was she supposed to know while she was equally in the dark? Reports Dora Motshabi,

I really did not know where he was. I was very thin ... Yet the Boers continued to ill-treat me. They would take me in their pick-up to the tenth floor of John Vorster Square. When I got there they would beat me ... They found that I did not know anything about his crossing. ${ }^{31}$

They promised a handsome amount of money for Dora Motshabi to serve as a spy regarding the whereabouts of Mandela, Sisulu and others, which she refused. She started receiving funds from America. She was questioned about

29 South African Democracy Trust, "Dora Motshabi,” 321.

30 South African Democracy Trust, "Dora Motshabi," 321.

31 South African Democracy Trust, "Dora Motshabi,” 322. 
the funds and then made a plan for the funds to reach her through her sister. The preceding information already gives us a glimpse about the challenges which were faced by women of departed husbands, women, for whom the exercise of waiting became their daily bread. At some point, Motshabi's house was nearly given to another man just because Dora was a woman.

In 1985 though, Dora found a way of being re-united with Motshabi in Zambia. However, she reports the atmosphere of their re-union as an unwelcoming one. Dora Motshabi visited her husband again in 1989. Her husband came back to South Africa in 1990. The re-union seems not to have been exciting as Dora Motshabi reports on what she views as an unthankful attitude on the part of a partner who had been an absent husband for many, many years:

He never appreciated that when he left there was no floor mat, no nice windows. He never appreciated that there was now somebody with a profession in the house, because our daughter Seithati is a teacher. ${ }^{32}$

After her husband's passing on, someone asked her if she was getting anything since her husband spent 27 years in exile. Her response was:

They only gave me after his death a lump sum of about R168 000.00 ... I tried to do something. I didn't want to buy a car first. I am old. I wanted to build the kids a home. That is when I built a bathroom. I even bought him a tombstone. ${ }^{33}$

Dora Motshabi is one of the many South African women who were able to engage actively and patiently in the taxing process of waiting. In her case, she was fortunate to get to know where her husband was, to get to visit him, and to get to have him re-united with the family even after his arrest on arrival in South Africa. Her narrative provides us with a window into the space of women who held the knife by its cutting edge when the head of the family was absent, a space in which women could serve both as a mother and father to their children in the absence of their spouses. Taxing and torturing as the exercise of waiting has been and continues to be, it proved to be worthwhile for her and for many of her sisters. It contributed, albeit not in an overt way, to African women's fight against the system of apartheid. Is there a comparable counterpart for Dora Motshabi in the HB? To the preceding question we now turn.

\section{F BATHSHEBA, A WAITING WOMAN?}

Perhaps Bathsheba had had a hectic day, ${ }^{34}$ not only as a household manager of Uriah's house, but also due to her involvement in the daily activities which an

32 South African Democracy Trust, "Dora Motshabi,” 323.

33 South African Democracy Trust, "Dora Motshabi,” 323.

34 Although some of the duties mentioned here may not have been performed with the intensity of Bathsheba's rural counterparts, also taking note of Meyers's observation that the economic productivity of women became reduced during the monarchic period, 
average Israelite woman could have engaged in. Perhaps she had spent her day involved in the necessary operations like soaking, milling, grounding, and baking, before her family could be able to eat the food. Maybe some of her children needed new clothes. As a result, she had to dedicate some of her day's hours to the shearing of wool, preparation of flax, the carding and spinning of thread, cloth weaving and the sewing of garments. Meyers reasons that on the average, for the better part of the year, many hours in a day would have been invested by Israelite women in some aspect of clothing manufacture. ${ }^{35}$ Two features come to light regarding women's economic involvement, first, they spent many hours in life-supporting activities per day and second, many of their tasks, if not all, involved some degree of technological expertise. ${ }^{36}$ Or could it be that Bathsheba's socio-economic class, ${ }^{37}$ unlike that of Dora Motshabi, relieved her from the economic responsibilities of her family?

As a parent actively involved in the educative role of her children, perhaps Bathsheba had to dedicate some of her time dealing with children who struggled to listen to the torah of their mothers. As one actively involved with the activities related to the religious life of the household, perhaps Bathsheba had been engaged in a family ritual where she had led the family in the prayers for an absent husband /father among others. In that way, she would have managed to let her children (cf. also Dora Motshabi's children) share communally in the taxing process of waiting, thus allowing the fruits of her womb to share in the emotional and psychological load linked to an absent husband/father. Apart from the fact that such prayers would have assisted her in the waiting-related stress, the stress connected with the (possible) return of Uriah, it would also have assisted the family in connecting with the absent member, at least in the spirit.

it is still safe to speculate that, seeing that Bathsheba was not attached to a rich man, she could have engaged in them. Cf. Carol L. Meyers, "Everyday Life: Women in the Period of the Hebrew Bible," in The Women's Bible Commentary, ed. Carol A. Newsom and Sharon H. Ringe (Louisville: Westminster/John Knox, 1992), 251. Regarding the latter fact, Meyers reasons "Urban development characterized the monarchic period. This shift had implications for female roles and status, because women probably remained economically productive in rural areas, but became less productive or even non-productive as urban wives of bureaucrats.” Carol L. Meyers, Discovering Eve: Ancient Israelite Women in Context (Oxford: Oxford University Press, 1998), 191.

35 Meyers, "Everyday Life," 247.

36 Meyers, "Everyday Life,” 247.

37 Douglas A. Knight's characterisation of cities as basically inhabited by the "powerful" comes to mind here. He reasons "... the several royal cities and the two capital cities were inhabited by those at the head of or directly responsible for the four major types of institutions centred here: the palace, the temple, the governmental administration, and the military.” Douglas A. Knight, Law, Power, and Justice in Ancient Israel, (Louisville, KY: WJK John Knox Press, 2011), 170,171. In my view, Uriah, Bathsheba’s absent husband would have fitted in the latter category. 
Whatever activities Bathsheba may have been engaged with, prior to her allocating a moment to herself alone, that moment of re-connecting with her body by taking a bath (2 Sam 11:2), does not seem to have been the interest of the narrator of her story as recorded in 2 Sam 11. As modern readers of this important female story, the story of a departed husband and a waiting woman, we can, informed by related stories in our different contexts (cf. the story of Dora Motshabi above), re-imagine and reconstruct what Bathsheba's day might have looked like before the evening of her bath.

Reading through her narrative in the text of 2 Sam 11, one is left with no shadow of doubt that it is not a story about Bathsheba, the waiting woman/wife, nor the story of a departed man/husband, a husband who seems to have been more loyal to the king than to his wife. It is a story of a powerful political leader, one whose power allowed him to send other men on war errands (2 Sam 11:1), while he chose to stay at home. The contrast between David and his men could hardly be expressed in starker terms. Staying home in such situations was not his usual practice of course (cf. 5:2; 8:1-14; 10:17). Indeed leading one's troops into battle was expected to be the major external activity of an ANE ruler (see 1 Sam 8:5-6, 20). Even though therefore reprehensible in itself, David's conduct on this occasion opens the way for royal behaviour that is even more despicable. ${ }^{38}$

David's power also enabled him to attempt to determine when Israelite men (read: warriors) could have sex with their wives. ${ }^{39}$ His power furthermore enabled him to indulge in sex with the waiting wives (2 Sam 11:4) of his warriors.

One evening when David arose from his bed and was walking on the roof of the king's house, from the roof he saw a woman bathing; and the woman was very beautiful. So David sent messengers, and took her; and she came to him, and he lay with her. When she had purified herself from her uncleanness, she returned to her house. The woman conceived. So she sent a message and reported to David, "I am pregnant.” (2 Sam 11:2, 4-5 MEV)

At face value, a reader may view the Bathsheba character of 2 Sam 11 as a passive person who was almost used like a pawn in the king's hands (cf. the expressions, "and took her," and "he lay with her” (cf. 2 Sam 11:2, 4-5. Jo Ann Hacket reasons, "Bathsheba is pictured as almost entirely passive in this episode; except for her first person message to David ('I am pregnant'; cf. 2 Sam 11:5),

38 Ronald F. Youngblood, “1 and 2 Samuel,” in Old Testament, Zondervan NIV Bible Commentary: An Abridgement of the Expositor's Bible Commentary, ed. Kenneth L. Barker and John R. Kohlenberger (Grand Rapids: Zondervan Publishing House, 1994), $1: 454$.

39 "Now David invited him to eat in his presence, and he drank until he got Uriah drunk. In the evening, he went to lie down in his lodging with the servants of his lord, but he did not go down to his house” (cf. 2 Sam 11:13, MEV). 
she is always spoken of in the third person." 40 Perhaps she could have chosen to enjoy her time of refreshment further (in the bath) as she reminisced on the absence of her husband. Alas! Her bathing time was suddenly interrupted as she was taken through the orders of the powerful. Who could have challenged the order from a king? Says the Northern Sotho proverb, "lentšu la kgoši le agelwa lešaka," the word from a traditional leader has a kraal built around it. Although the readers are basically not allowed to hear her own voice, Bathsheba is not inactive as I will show here below.

What could have preoccupied Bathsheba's thoughts at that moment, we may ask? May she have been haunted by what she would have to report to her returned husband on matters of female fidelity? It may not be an exaggeration to speculate that Bathsheba, a woman with a departed husband, was sexually starved. Loneliness, longings, and unfulfilled sexual desires typify some of the struggles faced by women whose husbands had gone to war, were in political exile and/or prison or were migrant labourers among others. It may not be an exaggeration to argue that sexual starvation was one of the critical albeit not openly spoken about challenges which typified the lives of many a waiting married woman both in biblical Israel and in pre-colonial and apartheid South Africa.

How may present day readers of the story understand the phrase, "and she came to him"? Did she come to the king willingly or not? Was there a particular reason why she decided to take her bath outside the house ${ }^{41}$ Could it be as Youngblood argued that the oppressive heat of the unusually warm spring could have forced her to go and bath outside, escaping the suffocating hot atmosphere of the house?

Although the mood of the text seems to be dominated by Bathsheba's passivity, she was not totally passive. She is portrayed as coming to the king. Before and during the sexual encounter, the reader cannot hear the load protest akin to that of Tamar when she protested against her rape by Amnon. After the act, she did not rush back to Uriah's house, she took another bath, this time not a leisure bath for refreshing her body. No! The latter bath was for the purification of her body (cf. Lev 15:25-26, 30.) Did he sleep with her in her uncleanliness? (Gen 25:4-5; 19:36; 25:21; 38:18; Exod 2:2).

40 Jo Ann Hackett, “1 and 2 Samuel,” in Women’s Bible Commentary, ed. Carol A. Newsom, Sharon H. Ringe and Jacqueline Lapsley (Louisville: Westminster/John Knox Press, 2012), 159.

41 Argues Hackett, "The only hint that she might have co-operated willingly in her predicament is her initial act of bathing in a place where she could be observed by the king out walking on his roof (not an uncommon place to stroll in the Middle East for the cool evening breeze).” Hackett, “1 and 2 Samuel,” 159. 
The cleansing bath, Bathsheba took not outside her absent husband's house, but inside the king's palace. While Bathsheba was taken to the man who chose to be present while others left their families to fight for the nation, her husband, one whose absence had forced her like her many South African counterparts, to engage in the taxing exercise of waiting, would soon be summoned by the same man for a calculated sexual re-union with his wife.

Once she discovered that she was pregnant, Bathsheba sent a word to report her pregnancy to the king. After the message of the pregnancy of Bathsheba, David went ahead to act in a foolish way, like a nabal. He did something unusual and suspicious. He sent a word for Uriah to return home with the hope that he could also control his sexual life. He had hoped to cover up for the sin of adultery which he had committed with Uriah's wife. His attempt at controlling the sexual appetite of Uriah though, failed dismally. David might have not understood the intensity of Uriah's loyalty to him ${ }^{42}$ and in particular, to Israel's deity: 43

Uriah responded to David, "The ark, Israel, and Judah dwell in makeshift shelters. My lord Joab and the officers of my lord are camping in the open field. But I may enter my house to eat, to drink, and to sleep with my wife? As you live and as your soul lives, I will not do this thing!” (2 Sam 11:11 MEV)

Could the actions of Uriah give readers some glimpse of the thoughts and actions of departed/absent husbands both in the HB and elsewhere? Could it be that absent men are not as yearning for their re-unions with their families, as their wives back home? Dora Motshabi's concerns about an apparently unthankful spouse come to mind here. Could it be that as Ndebele puts it, it is women who “... are prisoners of the dream of romance”? ${ }^{44}$ Perhaps departed men are more committed to the deity than they are to their anxiously waiting wives. When David's commitment to using Uriah as a cover-up for his adultery failed, he decided to let Uriah's departure from his family be a permanent one, not because of the conventional deaths from the military, but because of a calculated move by a leader who was supposed to protect his loyal warriors.

42 Uriah, one of David's warriors, depended on David for sustenance and support, hence the total loyalty that he gave in return. "Master of all he surveys, David had everything - and yet dies not having enough." Youngblood, "1 and 2 Samuel," 454.

43 Regina M. Swartz reasons: "Under the injunctions of holy war, to sleep with his own wife would be to be faithless to God; it is that fidelity, to his deity, that Uriah maintains, despite the obvious attractiveness of his wife, despite his drunkenness, and it is that fidelity to his deity that he finally dies for." Regina M. Swartz, "Adultery in the House of David: The Metanarrative of Biblical Scholarship and the Narratives of the Bible,” in Woman in the Hebrew Bible, ed. Alice Bach (New York: Routledge, 1998), 346.

44 Ndebele, Winnie Mandela, 21. 
Masenya, “Absent Husbands and Waiting Wives,” OTE 30/2 (2017): 384-402 399

When the news about the death of her absent husband reached Bathsheba, when the reality of the end of her waiting dawned, she mourned for her husband (2 Sam 11:26). Through Uriah's death, Bathsheba joined the ranks of many black South African women who waited for their husbands only to be greeted by their permanent absences with their deaths being the most common occurrence.

\section{G CONCLUSION}

Schlegel offers a helpful remark about forces leading to sexual stratification from a cross-cultural perspective. Differentiation in sex roles is a response to both the internal dynamics of a society and to the external conditions to which a society must respond. Society's central institutions and the degree to which they favour one sex or the other, need to be critically examined. She argues, "Where economic production favors male control, as in colonial Ghana, or where male-controlled military activities are central, as in the feuding pattern among Israeli Arab clans, male activities become predominant and men come to be the primary decision makers in almost all aspects of social life."45

I have thus always been fascinated by the apparent points of resemblance between women (and men) and their position/roles especially in pre-monarchic Israel and pre-colonial and apartheid Africa. One example can serve as a case in point: In both settings, there was a blurred division between the activities performed by men and women in the private and public spheres. In fact, there appears to be a similar pattern that the elevation of the public (mostly or solely male sphere) seem to happen when something strange or foreign, something not organic to that specific context, occurs. Israelite men and women for example worked harmoniously towards the overall welfare of the family. In fact, work done by women in the "private" sphere towards the survival of families, was not only more taxing, it also required certain skills. With the introduction of the monarchy though, the separation between the two spheres not only became foregrounded, the gendered nature of the work done in both spheres usually led to work performed by women being devalued and the form of egalitarianism that might have been visible earlier on, becoming problematized. Also, the monarchy with its commitment to seeking and preserving power, protecting the people, would entail the involvement of men in wars. The reality of departing and absent husbands would also set in. Coupled with the preceding fact would then be the harsh reality of waiting wives. The exercise of waiting and all that goes with it, thus became not only an ugly intrusion, but a serious disruption to closely knit families.

45 Alice Schlegel, “An Overview,” in Sexual Stratification: A Cross-cultural View, ed. Alice, Schlegel 9New York and Guilford, Surrey: Columbia University Press, 1977), 354-355. 
With the introduction of the migrant labour system in South Africa, for example, came not only the disturbance and disruption of African families, work done by men in the private sphere came to be more valued than that done by women in the private sphere of the home. Had such disruption by foreign forces not occurred, African people could have continued to navigate life ably. The words of Elen Kuzwayo comes to light:

That black people at that time were owners of the land they tilled and cultivated; that they formed a community with an established cultural and moral code as well as a valid economic structure; these factors together with many others which contributed to the stability and prosperity of individual families, meant that the majority of the black population found no pressing need to leave their homes to go in search of employment. ${ }^{46}$

Not only were the closely knit African families disrupted, the lives of African women would begin to be typified not only by absent husbands, but also by the long wait for their men's return. Such an exercise of waiting was also intensified as we have observed in Dora Motshabi's narrative above, during the heyday of apartheid when African men crossed the borders into exile. Some men were incarcerated or even killed, not in ordinary wars as in biblical Israel, but in the black people's “war” /struggle to challenge life-denying foreign systems.

The above investigation has hopefully revealed that an incorporation of the discipline of Biblical Studies within the MIT's, may support the important argument raised last August by Professor Mandla Makhanya, ${ }^{47}$ the Vice Chancellor and Principal of the University of South Africa. He was addressing a meeting of the UNISA's Black Forum. Makhanya argued that unless one's research as an academic is made useful to the communities in which they serve, it would remain useless. The urgency of integrating one's research in one's disciplines with our communities is even felt urgently by those African contexts like South Africa, in which Eurocentric epistemologies have dominated and to some extent, continue to dominate academic offerings. In the preceding example, the African proverbial lore was not only foregrounded, but was also used as an integral part of the subject matter of Biblical Studies thus enhancing the usability of the latter especially within our African contexts. The global contexts will also benefit from the knowledge that Africa, like other continents whose inhabitants were colonised, were not clean slates before foreign intrusion and interference. The Indigenous Knowledge Systems (IKS’s) have to be revived and harnessed.

46 Elen Kuzwayo, "Hungry in a Rich Land," in Sometimes When it Rains: Writings by South African women, ed. Ann Oosthuizen (London: Pandora, 1987), 99.

47 Mandla S. Makhanya, "Professor MS Makhanya's meeting with the Unisa Black Forum," Unpublished Speech addressed to the members of the Black Forum, University of South Africa, Pretoria, 22 August 2016. 
Masenya, “Absent Husbands and Waiting Wives,” OTE 30/2 (2017): 384-402 401

In its context, the present article also revealed the need for the resuscitation of the herstories of forgotten heroines like the many wives who engaged and still engage in the exercise of running families in the absence of their husbands. These heroines, who are often not celebrated had the audacity and patience to wait and thus sustained their families. Something of these women's tenacity may perhaps be copied by many a South African biblical scholar who is committed to a rewarding, fulfilling, MIT-conscious Biblical Studies.

\section{BIBLIOGRAPHY}

Bach, Alice, ed. Women in the Hebrew Bible. New York: Routledge, 1999.

Bezuidenhout, Jacobus S. “Die Noord-Sotho spreekwoord en -gesegde: 'n Stilistiese analise.” MA diss., University of Potchefstroom, 1981.

Brandes, Stanley H. “The Selection Process in Proverbs Use: A Spanish Example.” SFQ 38 (1974): 167-186.

"College of Human Sciences: About the College.” UNISA. http://www.unisa.ac.za /sites/corporate/default/Colleges/Human-Sciences/About-the-college.

Duminy, Pieter A. African Pupils and Teaching Them. Pretoria: Van Schaik, 1967.

Finnegan, Ruth. Oral Literature in Africa. Oxford: Oxford University, 1970.

Guma, Samson M. The Form, Content and Technique of Traditional Literature in Southern Sotho. Pretoria: Van Schaik, 1977.

Hackett, Jo Ann. “1 and 2 Samuel.” Pages 150-163 in Women's Bible Commentary. Edited by Carol A. Newsom, Sharon H. Ringe and Jacqueline Lapsley. Louisville: Westminster/John Knox Press, 2012.

"Institute for Open and Distance Learning (IODL): Attending to Your Needs." UNISA. http://www.unisa.ac.za/sites/corporate/default/Colleges/GraduateStudies/Schools,-Institutes-\&-Research-Chairs/School-of-TransdisciplinaryResearch-Institutes-(STRI)/Institute-for-Open-and-Distance-Learning(IODL)/Attending-to-your-needs).

Knight, Douglas A. Law, Power, and Justice in Ancient Israel. Louisville: Westminster/John Knox, 2011.

Krappe, Alexander H. The Science of Folklore. London: Methuen, 1965.

Kuzwayo, Elen. "Hungry in a Rich Land.” Pages 99-108 in Sometimes When it Rains: Writings by South African Women. Edited by Ann Oosthuizen. London: Pandora, 1987.

Meyers, Carol L. "Everyday Life: Women in the Period of the Hebrew Bible.” Pages 244-251 in The Women's Bible Commentary. Edited by Carol A. Newsom and Sharon H. Ringe. Louisville: Westminster/John Knox, 1992. . Discovering Eve: Ancient Israelite Women in Context. Oxford: Oxford University Press, 1998.

Makhanya, Mandla S. "Professor MS Makhanya's meeting with the Unisa Black Forum.” Unpublished Speech addressed to the members of the Black Forum. University of South Africa, Pretoria, 22 August, 2016.

Masenya, Madipoane. "Biblical Studies in South(ern) Africa: An Overview.” Pages 454-465 in Handbook of Theological Education in Africa. Edited by Isabel A. Phiri and Dietrick Werner. Pietermaritzburg: Cluster Publications, 2013.

McLaren, James. "The Wit and Wisdom of the Bantu as Illustrated in their Proverbial Sayings.” SAJS 14 (1977): 330-334. 
402 Masenya, “Absent Husbands and Waiting Wives,” OTE 30/2 (2017): 384-402

Monyamane, R. A. “The Northern Sotho Proverb: A Survey of the Northern Sotho Proverb with Respect to its Definition, Characteristics, Classification, Form and its Functional Value/Significance.” Honours article, University of South Africa, 1979.

Ndebele, Njabulo. The Cry of Winnie Mandela. Claremont: David Philip, 2008. Nyembezi, Cyril L. Zulu Proverbs. Johannesburg: Witwatersrand University, 1954.

Pityana, Barney N. "Open Distance Learning in the Developing World: Trends, Progress and Challenges.” Keynote address at the 23rd ICDE World Conference on Open Learning and Distance Education on Flexible Education for All, OpenGlobal-Innovative, 7-10 June 2009, Maastricht, the Netherlands. http: //uir.unisa.ac.za/bitstream/handle/10500/411/ICDEMaastricht250609.pdf?seque $\underline{\text { nce }=1 .}$.

Rakoma, J. R. D. Marema-ka-dika Tša Sesotho sa Leboa. Pretoria: J. L. Van Schaik, 1971.

Seitel, Peter. Proverbs and the Structure of Metaphor among the Haya of Tanzania. Michigan: Ann Arbor, 1972.

Spangenberg, Izak (Sakkie) J. J. "Paradigm Changes in the Bible Sciences and the Teaching of Biblical Studies in the New South Africa.” Scriptura 52 (1995): 110.

Tladi, Miriam. "Interview with Mrs Albertina Sisulu.” Pages 170-178 in Sometimes When it Rains: Writings by South African Women. Edited by Ann Oosthuizen. London: Pandora, 1987.

Schlegel, Alice. “An Overview.” Pages 354-355 in Sexual Stratification: A CrossCultural View. Edited by Alice Schlegel. New York: Columbia University Press, 1997.

South African Democracy Trust., ed. "Dora Motshabi.” Pages 319-324 in The Road to Democracy: South Africans Telling their Stories, Volume 1, 1950-1970. Edited by South African Democracy Trust. Hollywood: Tsehai Publishers and Distributors, 2008.

. "Ruth Mompati." Pages 307-318 in The Road to Democracy: South

Africans Telling their Stories, Volume 1, 1950-1970. Edited by South African

Democracy Trust. Hollywood: Tsehai Publishers and Distributors, 2008.

Swartz, Regina M. "Adultery in the House of David: The Metanarrative of Biblical Scholarship and the Narratives of the Bible.” Pages 335-350 in Women in the Hebrew Bible. Edited by Alice Bach. New York: Routledge, 1998.

Youngblood, Ronald F. “1 and 2 Samuel.” Pages 378-486 in Old Testament. Edited by Kenneth L. Barker and John R. Kohlenberger. Vol. 1 of Zondervan NIV Bible Commentary: An Abridgement of the Expositor's Bible Commentary. Grand Rapids: Zondervan Publishing House, 1994.

Ziervogel, D. and Pothinus C. Mokgokong. Comprehensive Northern Sotho Dictionary. Pretoria: Van Schaik, 1975.

Prof. Madipoane Masenya (ngwan’a Mphahlele), Department of Biblical and Ancient Studies, University of South Africa, PO Box 392, 0003 Unisa, RSA. Email: masenj@unisa.ac.za. 